\title{
Computer Program to Select Suitable Tractor Implement System for Paddy-Wheat Cropping System
}

\author{
T.K. Maheshwari ${ }^{1 *}$ and Uday Veer Singh ${ }^{2}$ \\ ${ }^{1}$ Dr. BRA College of Agricultural Engineering and Technology, Etawah, UP, India \\ ${ }^{2}$ Department of Farm Machinery and Power Engineering SHUATS Allahabad, UP, India \\ *Corresponding author
}

\section{A B S T R A C T}

\begin{tabular}{|l|}
\hline K e y w o r d s \\
Tractor, Paddy- \\
Wheat, Implements, \\
C- Language, \\
PMSM
\end{tabular}

Procedures for the selection of optimal power source are time consuming and laborious even for a few sets of operations. Computer based interactive mathematical model are, therefore, required for finding solutions for the given farming system. The objective of the present work is to make Computer program in $\mathrm{C}$ language to select suitable tractor implement system for Paddy-Wheat cropping system. The cost components associated in the selection of field machinery were fixed, operating and timeliness cost. The program was based on the optimum size of the tractor and its matching implements. The program had the capabilities of computing the operational work hours, human and mechanical energy requirement, fixed, operating and timeliness cost for different operations of both crop. The computer program PMSM consisted of two sub programs, namely, tractor and machinery selection model (TMSM) and stationary power selection model (SPSM). The program was used to select combination of power sources and farm equipment suitable for different farm sizes.

\section{Introduction}

Indian Agricultural is in the state of technological transformation. Improved technique of crop production and processing developed through scientific and innovations are replacing the traditional practices.

Modern farming system requires large capital investments, complex economic decisions and higher levels of technical management to maximize profits. Machinery cost depends on not just one machine or operation, but on the whole system of machines with power provided by tractors or other prime movers.
Computer based interactive mathematical model are, therefore, required for finding solutions for the given farming system.

Optimum machinery selection and management depend on system cost, as machinery contributes a major capital input cost in most farming situations and thereby the net returns (Hetz and Esmay, 1986 and Ismail, 1998). Murthy (1999) developed software in BASIC language for determining the optimum power requirement that gave the economical agricultural production for a known farm size, and farm operations using Hunt's least cost equation. 


\section{Materials and Methods}

\section{Development of the computer programs}

The program was based on the optimum size of the tractor and its matching implements. The program had the capabilities of computing the operational work hours, human and mechanical energy requirement, fixed, operating and timeliness cost for different operations of both crop.

The program also computed the system hours and system cost, net profit and custom hours required for the given form size.

The computer program was divided into series of sub modules to maintain the flexibility and user friendliness. Stored data files were used to limit the amount of data required from the user and were not designed to be changed by the user. The stored data files used in the program are described below.

\section{Paddy.dat}

This file contained data on equipment used for different field operations of paddy crop.

\section{Wheat.dat}

This file contained data on equipment used for different field operations of wheat crop.

\section{Machine.dat}

This file contained information like economic life of equipment including power sources, average price per unit width/capacity, repair and maintenance factor $(\mathrm{R} \& \mathrm{M})$, speed of operation, number of passes, efficiency, yield loss due to delay in any operation, optimum time available for each operation and load factor for all the equipment and power sources for paddy and wheat crop. This file also included the sale price of the paddy and wheat grains. A zero in the data file indicated that information was irrelevant for the particular equipment or power source.

The flow charts illustrating the procedure and the logic of the developed computer program for the selection of optimum farm power and machinery are given in Figure. The functional outline of the main module of the program is shown in the Figure 1 shows the flow chart of TMSM. Brief description of the selection procedure for tractor and machinery follows:

The program first read the input information given in the data files.

Power requirement for paddy and wheat were computed separately.

Tractor power was determined using the model based on crop requiring maximum power.

Tractor size was selected based on the market availability.

Annual use of tractor was assumed (EWHT).

Optimum sizes of equipment were determined

\section{Results and Discussion}

This chapter includes the results of the study and discussion of the results with respect to the objectives already set out. Specifically, least cost mathematical models for the selection of optimum size of power source and machinery system; information on cultural practices followed, power units and machinery used for paddy wheat cropping system in the study area; comparison of the model output with different farm categories of the study area and recommendation for optimum power and machinery combination for paddy wheat cropping system have been presented and discussed in that order (Fig. 1-3). 
Int.J.Curr.Microbiol.App.Sci (2018) 7(4): 2381-2387

Table.1 Test result of tractor drawn mould board plough

\begin{tabular}{|c|c|c|c|c|c|c|c|}
\hline $\begin{array}{l}\text { Sl. } \\
\text { No. }\end{array}$ & $\begin{array}{l}\text { Speed } \\
(\mathrm{km} / \mathrm{h})\end{array}$ & $\begin{array}{c}\text { Theoretical } \\
\text { field } \\
\text { capacity, } \\
\text { (ha/h) }\end{array}$ & $\begin{array}{l}\text { Actual } \\
\text { field } \\
\text { capacity, } \\
\text { (ha/h) }\end{array}$ & $\begin{array}{c}\text { Field } \\
\text { efficiency, } \\
(\%)\end{array}$ & $\begin{array}{l}\text { Depth of } \\
\text { cut, } \\
\text { (cm) }\end{array}$ & $\begin{array}{l}\text { Draft, } \\
(\mathbf{k N})\end{array}$ & $\begin{array}{l}\text { Energy } \\
\text { required, } \\
\text { (kWh/ha) }\end{array}$ \\
\hline $\begin{array}{l}1 . \\
2 . \\
3 .\end{array}$ & $\begin{array}{l}4.70 \\
4.32 \\
4.70\end{array}$ & $\begin{array}{l}0.42 \\
0.39 \\
0.42\end{array}$ & $\begin{array}{l}0.33 \\
0.32 \\
0.34\end{array}$ & $\begin{array}{l}79.00 \\
82.00 \\
81.00\end{array}$ & $\begin{array}{l}20.00 \\
18.00 \\
21.00\end{array}$ & $\begin{array}{l}8.09 \\
6.62 \\
8.58\end{array}$ & \begin{tabular}{|l|l|}
32.02 \\
24.83 \\
32.96 \\
\end{tabular} \\
\hline Average & 4.57 & 0.41 & 0.33 & 81.00 & 19.67 & 7.76 & 29.94 \\
\hline
\end{tabular}

Table.2 Test result of tractor drawn disc harrow

\begin{tabular}{|c|c|c|c|c|c|c|c|}
\hline $\begin{array}{l}\text { Sl. } \\
\text { No. }\end{array}$ & $\begin{array}{c}\text { Speed } \\
(\mathrm{km} / \mathrm{h})\end{array}$ & $\begin{array}{c}\text { Theoretical } \\
\text { field } \\
\text { capacity, } \\
\text { (ha/h) }\end{array}$ & $\begin{array}{l}\text { Actual } \\
\text { field } \\
\text { capacity, } \\
\text { (ha/h) }\end{array}$ & $\begin{array}{c}\text { Field } \\
\text { efficiency, } \\
(\%)\end{array}$ & $\begin{array}{c}\text { Depth } \\
\text { of cut, } \\
(\mathrm{cm})\end{array}$ & $\begin{array}{c}\text { Draft, } \\
(\mathbf{k N})\end{array}$ & $\begin{array}{l}\text { Energy } \\
\text { required, } \\
\text { (kWh/ha) }\end{array}$ \\
\hline $\begin{array}{l}1 . \\
2 . \\
3 .\end{array}$ & $\begin{array}{l}5.68 \\
6.00 \\
6.35\end{array}$ & $\begin{array}{l}0.91 \\
0.96 \\
1.02\end{array}$ & $\begin{array}{l}0.73 \\
0.77 \\
0.85\end{array}$ & $\begin{array}{l}80.00 \\
80.00 \\
83.00\end{array}$ & $\begin{array}{l}15.00 \\
14.00 \\
15.00\end{array}$ & $\begin{array}{l}5.39 \\
5.89 \\
6.62\end{array}$ & $\begin{array}{l}11.65 \\
12.75 \\
13.74\end{array}$ \\
\hline Average & 6.01 & 0.96 & 0.78 & 81.00 & 14.67 & 5.97 & 12.71 \\
\hline
\end{tabular}

Table.3 Test result of tractor drawn 11-tyne cultivator

\begin{tabular}{|c|c|c|c|c|c|c|c|}
\hline Sl. No. & $\begin{array}{c}\text { Speed } \\
(\mathrm{km} / \mathrm{h})\end{array}$ & $\begin{array}{c}\text { Theoretical } \\
\text { field } \\
\text { capacity, } \\
\text { (ha/h) }\end{array}$ & $\begin{array}{l}\text { Actual field } \\
\text { capacity, } \\
(\mathrm{ha} / \mathrm{h})\end{array}$ & $\begin{array}{c}\text { Field } \\
\text { efficiency, } \\
(\%)\end{array}$ & $\begin{array}{c}\text { Depth } \\
\text { of cut, } \\
\text { (cm) }\end{array}$ & $\begin{array}{c}\text { Draft, } \\
(\mathrm{kN})\end{array}$ & $\begin{array}{l}\text { Energy } \\
\text { required, } \\
\text { (kWh/ha) }\end{array}$ \\
\hline $\begin{array}{l}1 . \\
2 . \\
3 .\end{array}$ & $\begin{array}{l}6.00 \\
6.00 \\
6.35\end{array}$ & $\begin{array}{l}1.44 \\
1.44 \\
1.52\end{array}$ & $\begin{array}{l}1.16 \\
1.14 \\
1.20\end{array}$ & $\begin{array}{l}81.00 \\
79.00 \\
79.00\end{array}$ & $\begin{array}{l}10.50 \\
10.00 \\
10.50\end{array}$ & $\begin{array}{l}6.13 \\
5.88 \\
6.38\end{array}$ & $\begin{array}{l}8.81 \\
8.61 \\
9.38\end{array}$ \\
\hline Average & 6.12 & 1.47 & 1.17 & 80.00 & 10.30 & 6.13 & 8.93 \\
\hline
\end{tabular}


Fig.1 Flow chart of the main module of the tractor and machinery selection model

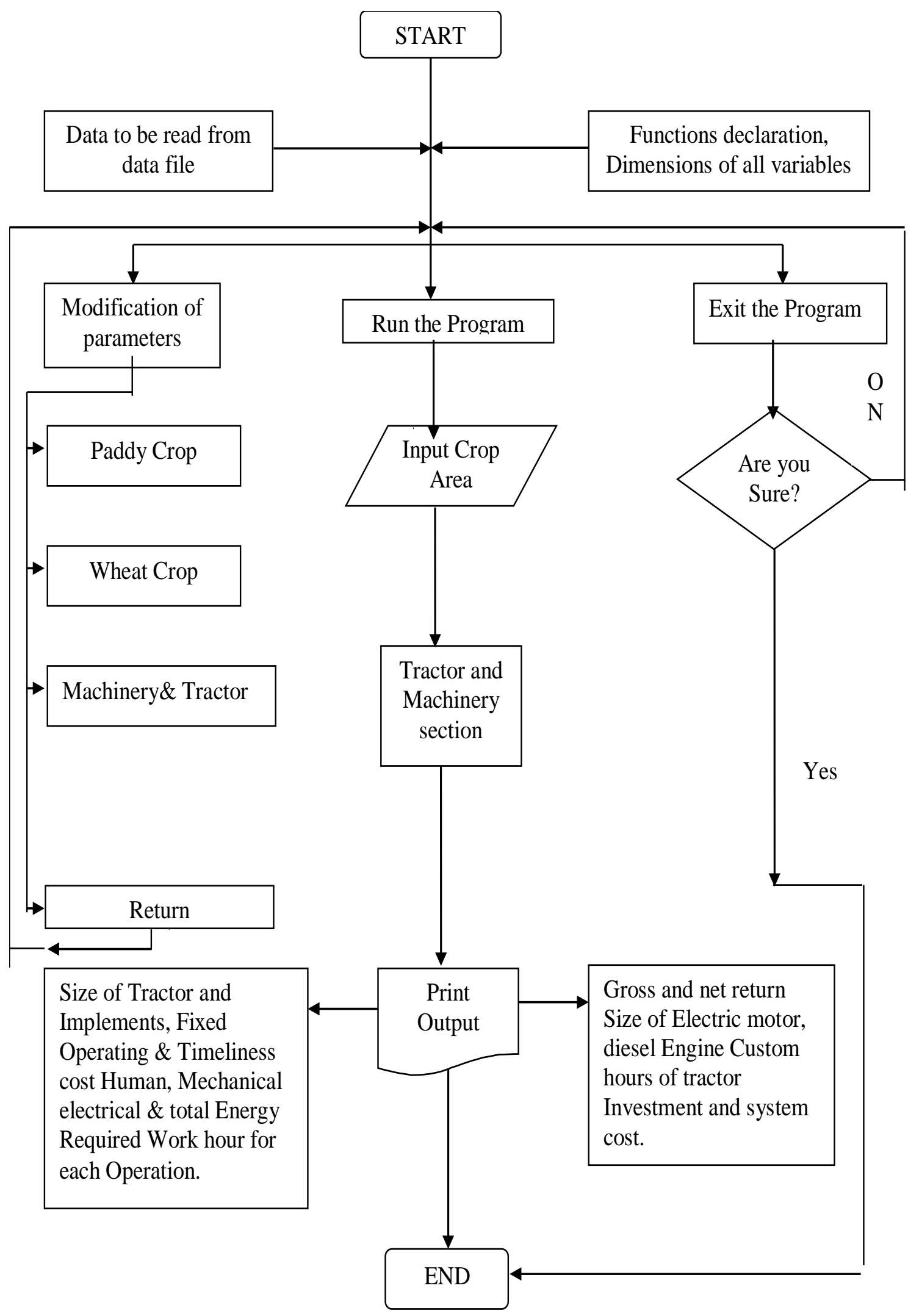


Fig.2 Energy required for various operation for a 10 ha farm

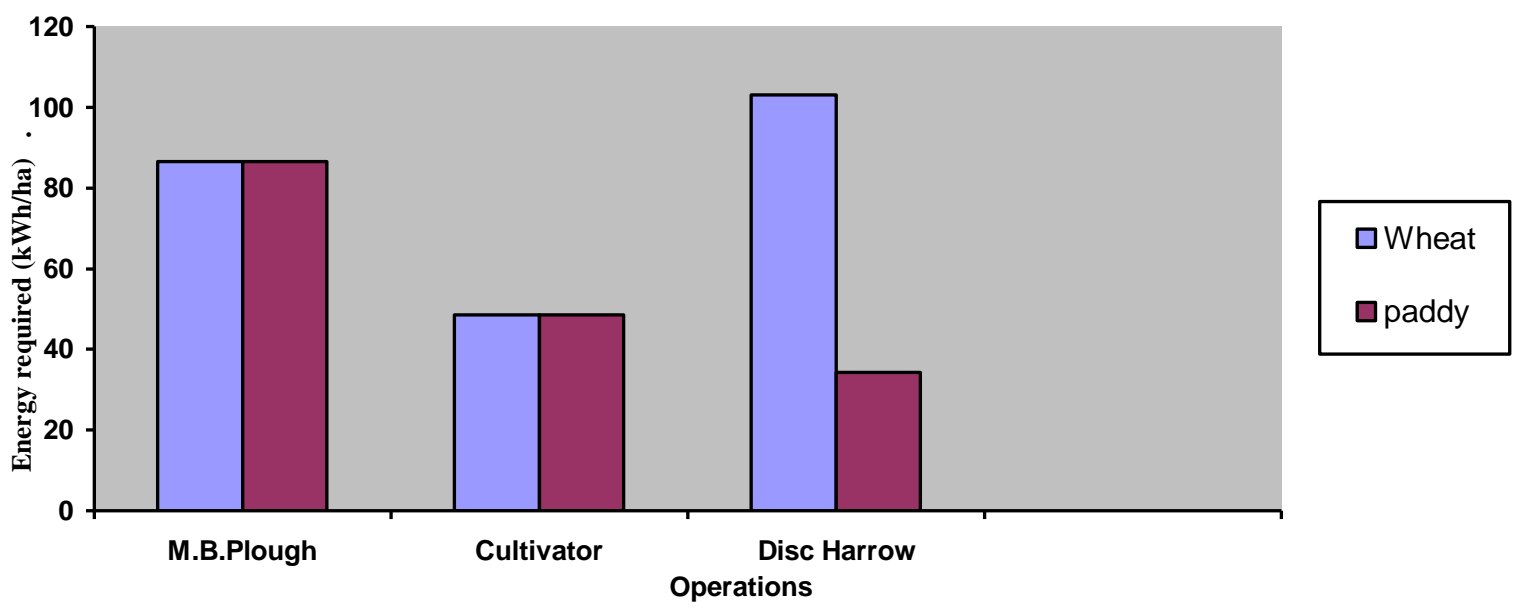

Fig.3 Different components of tractor-machinery cost VS farm size

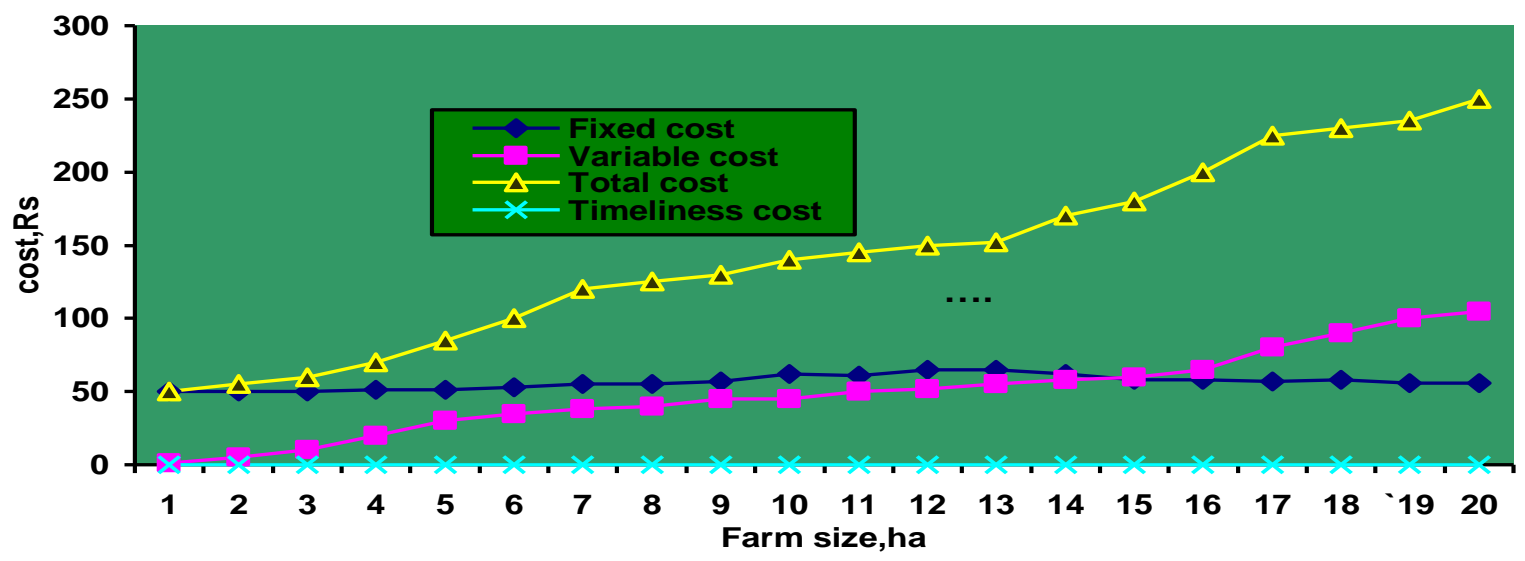

Fig.4 Tractor-machinery cost per unit area

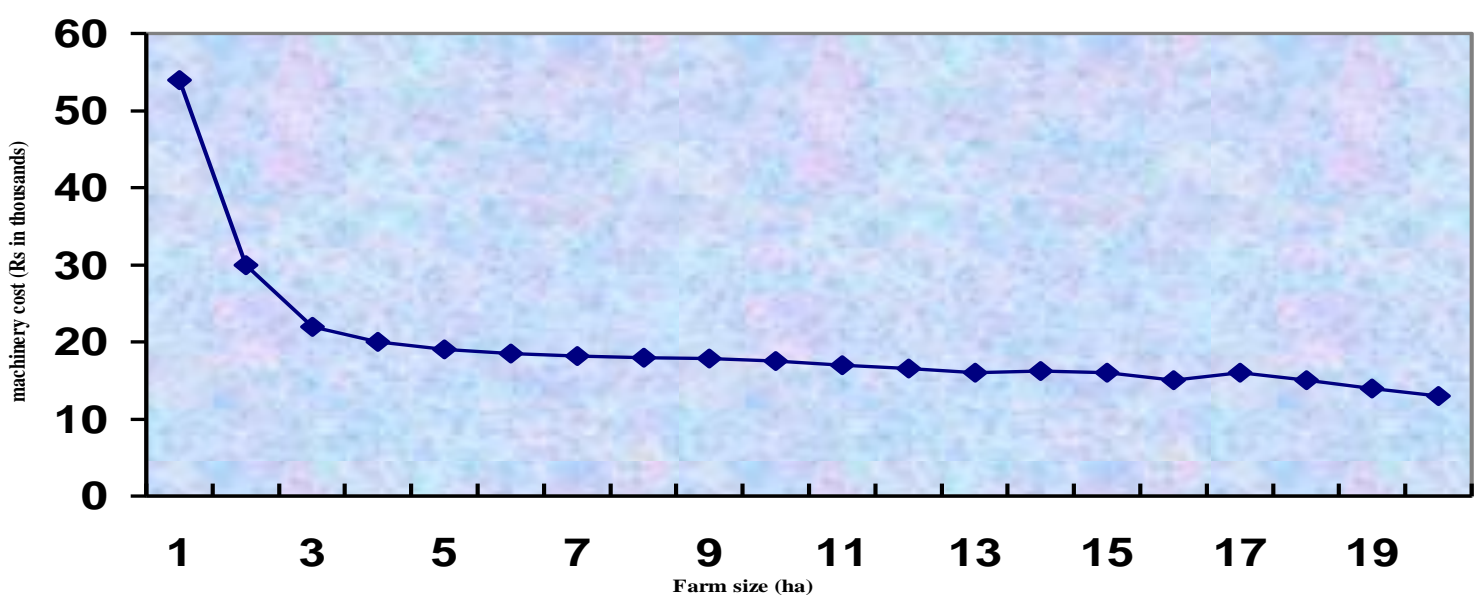




\section{Power and machinery selection models}

The power machinery selection models (PMSM) developed in this study was based on the least-cost method or minimization of total cost of power sources and machinery package for the given farming situation. The computer program PMSM consisted of two sub programs, namely, tractor and machinery selection model (TMSM) and stationary power selection model (SPSM). But here we are discussing only about TMSM.

\section{Development of database}

\section{Primary sources}

There were two primary sources of information used in this study, namely, field experiments and the survey of farm equipment manufacturers. The results of the $3 \times 30 \mathrm{~cm}$ mould board plough, tested in sandy loam soil at moisture contents and bulk density of $10.5 \%(\mathrm{db})$ and 1.35 gram per cc, respectively are shown in table 1 . The actual field capacity and field efficiency of the mould board plough ranged between 0.32 to 0.34 ha per hour and 79 to $80 \%$ respectively. The result of 8X8 Disc harrow tested at soil moisture of $9.0 \%(\mathrm{db})$ and bulk density of $1.25 \mathrm{gm}$ per cc is given in table 2 . The field efficiency of the disc harrow was found to be $81 \%$ at the average operating speed of 6.01 $\mathrm{km}$ per hour

Table 3 includes the test result of 11-tyne cultivator tested at soil moisture of $9 \%(\mathrm{db})$ and bulk density of $1.25 \mathrm{gm}$ per $\mathrm{cc}$. the actual field capacity of the cultivator was found to be 1.17 ha per hour at the operating speed of $6.12 \mathrm{~km}$ per hour.

\section{Tractor-machinery cost}

The fixed cost and variable cost of tractor machinery system increased with the farm size. It may be seen that from graph that as the farm size increased the variable cost increased at a much higher rate than the fixed cost. The difference between the fixed and variable cost for 1 ha farm was nearly Rs. $40,000.00$ and it gradually narrowed down as farm size increased.

Marginal farmers in the study area did not own tractor. This category depended completely on custom hiring

Tractors up to $26 \mathrm{~kW}$ (35 hp) were very popular among the farmers of the study area and were possessed by $71 \%$ of the farmers of the sample were as tractor above $35 \mathrm{hp}$ were owned by only $38 \%$ of the farmers. Small and semi medium farmers had tractors below 35 hp. (Source: KVK Etawah.)

Disc harrow was the most popular implements among farmers and owned by $96 \%$ of the farmers in the sample followed by cultivator $87.96 \%$. Seed cum fertilizer was the least use equipment and owned by only $7.4 \%$ of the farmers. (Source: KVK Etawah.).

On an average the tractor machinery cost constituted $30 \%$ of the total system cost.

Total cost of production for paddy crop was higher than wheat crop while the net return of paddy was lower than wheat, for farm sizes in the ranges of 1 to 20 ha. (Source: KVK Etawah.)

The model was found to be sensitive to the input parameters

\section{References}

Balasanki, P.K. and Saloke, V. M. 1999. A case study of tractor utilization by farmers, Coimbatore district, India AMA, 30(3):14-18. 
Chancellor, W. J. 1969. Selecting optimum sized tractor. Trans. of ASAE. 12(4): 411-414\& 418.

Hetz, E. J. and Esmay, M. L. 1986. Optimization of machinery systems. AMA. 17(1): 68-76

Ismail, W.I.W 1998. Cost analysis model for crop production machinery system. AMA. 29(4): 56-60.

Murthy, N.R. 1999. a software for agricultural machinery management selection of optimum power. $J$. of the Institution of Engineers (India)-Ag. 79(2): 39-42.

Singh, B., Singh. K. N., Thakur, T. C. and Kumar, A. 1991. Tractor power utilization on mechanical farms. AMA. 22(2): 44-48.
Singh, G. and Gupta, M. L. 1980. Machinery selection for farms in north India. Agicultural systems. 6(1):93-120

Ward, S. M. Mcnutlty, P. B. and Cuney, M. B., 1985. Repair costs of two and four wheel drive tractors. Trans of ASAE. 28(4):1074-1076.

Witney, B. D. and Oskoui, K. E. 1982. The basis of tractor power selection on arable farms. Journal of Agricultural Engineering Research. 27 (6):513-527

Yadav, S and Bhalla, D. 1999. Utilization pattern of farm tractors in District Mohindergarh (Haryana). Agricultural Engineering today. 23 (1-2):65-76

\section{How to cite this article:}

Maheshwari, T.K. and Uday Veer Singh. 2018. Computer Program to Select Suitable Tractor Implement System for Paddy-Wheat Cropping System. Int.J.Curr.Microbiol.App.Sci. 7(04): 2381-2387. doi: https://doi.org/10.20546/ijcmas.2018.704.273 